the water is hydrogen-bonded both intermolecularly and to hydroxyl groups on the $\mathrm{SiO}_{2}$ surface. A new approach to this problem was provided by J. A. Hockey et al. (Manchester College of Science and Technology), who measured the heats of immersion of dehydrated silica in water. From the results they deduced that the distribu. tion of residual $\mathrm{OH}$ groups on a dehydrated silica surface depends on the conditions of outgassing; sintering in air facilitates redistribution of the $\mathrm{OH}$ groups to sites of lowest energy. Two other papers, both by P. J. Anderson and colleagues (Harwell), were devoted to water adsorption on magnesia, an oxide which has been much less studied in this context. Infra-red absorption measurements revealed the surface dehydration-hydration cycle not to be reversible; rather it seems that dehydration leads to a small change in the surface ionic arrangement such that subsequent rehydration occurs to form hydroxyl groups which are bonded differently. This general picture is confirmed and amplified by proton magnetic resonance studies of ehemisorbed and physically absorbed water on MgO. These measurements suggest that hydruxyl groups on a partially dehydrated surface may form small clusters. The application of nuclear magnetic resonance to surface chemistry is of recent origin and promises to be a powerful analytical tool for selected problems in adsorption. The remaining papers on water adsorption were by S. J. Gregg et al. (University of Exeter) and by D. Hardy and N. J. Petch (University of Newcastle). Gregg presented water adsorption isotherms for a number of oxides, $\mathrm{Fe}_{2} \mathrm{O}_{3}, \mathrm{SnO}_{2}, \mathrm{SiO}_{2}$ and $\mathrm{TiO}_{2}$. Silica is particularly interesting as it is hydrophobic after calcination at $900^{\circ} \mathrm{C}$, but slowly regains its hydrophilic nature during prolonged exposure to water vapour at $25^{\circ} \mathrm{C}$. Hardy and Petch in their paper considered the lowering in the surface energy of $\gamma$-and $\alpha$-alumina brought about by water adsorption.
The experimental decrease in surface energy, calculated from adsorption isotherms, is quite insufficient to account for the reduction in fracture stress of $\mathrm{Al}_{2} \mathrm{O}_{3}$ observed in the presence of water vapour.

The final afternoon session comprised three miscellaneous papers each interesting in its own way. R. A. Ross and A. H. Taylor (College of Technology, Belfast) extended their earlier work on ammonia adsorption on silica gel with a new study of ethylamine adsorption. R. L. Nelson et al. (Harwell) discussed the influence of irradiation on the chemisorption of oxygen on $\mathrm{MgO}$ and $\mathrm{CaO}$. Electron spin resonance techniques were exploited to provide information on irradiation-induced surface defects and their role in chemisorption. Finally, J. K. Higgins (Harwell) provided a beautiful illustration of how a technologically oriented study may lead to results of considerable scientific interest. In an investigation of the reaction of alumina with caesium vapour, neutron irradiation was found to enhance the reaction considerably. The effect was attributed to minor cracking in the alumina, resulting from irradiation-induced lattice expansion.

From the foregoing brief account it will be seen that the symposium, while directed towards a central theme, embraced papers which were concerned with a wide variety of experimental techniques and with diverse types of ceramic material. This follows a pattern set by recent meetings of the Basic Science Section of the British Ceramic Society. Such meetings are especially valuable in fostering an exchange of ideas between scientists drawn from different disciplines and industries but united by a common interest. From the lively discussion which developed, one may conclude that the present symposium succeeded in this aim. Much of the credit for this success must go to the organizer, Dr. P. J. Anderson.

R. M. Deur

\title{
ANIMAL AND PLANT TISSUE CULTURE
}

\begin{abstract}
A SEMINAR on animal and plant tissue culture was held at the Department of Biochemistry, M.S. University of Baroda, Baroda, India, under the auspices of the University Grants Commission and the M.S. University of Baroda, during January 21-28. Prof. C. V. Ramkrishnan, head of the Department of Biochemistry, M.S. University of Baroda, was the director of the seminar. This was the second conference on tissue culture to be held in India, the first having been held at the Department of Botany, University of Delhi, under the auspices of the Unesco South Asia Science Co-operation Office, New Delhi, in December 1961. The latter, however, has been confined to plant tissue culture.

The present seminar was attended by about sixty delegates, drawn not only from different parts of India but also from overseas, and they included biochemists, botanists, zoologists and virologists. The overseas visitors included: Dr. C. R. Anderson (now at the Virus Research Centre, Poona); Prof. E. J. Ambrose (Chester Beatty Research Institute, London); Dr. Endo Hiroyoshi (University of Tokyo); Dame Honor B. Fell (Strangeways Research Laboratory, Cambridge); Prof. H. Katsuta (Tokyo University); Prof. J. Paul (University of Glasgow); Prof. M. D. Rosemberg (Tho Rockefeller Institute, New York); and Prof. C. H. Waddington (University of Edinburgh).
\end{abstract}

Dr. C. S. Patel, vice-chancellor, M.S. University of Baroda, welcomed the delegates, and Dame Honor B. Fell delivered the inaugural address in which she outlined the history of the development of animal tissue culture studies.

The seminar consisted of fifteen sessions: two for animal organ culture, seven for animal cell culture, two for virology, and four for plant tissue culture. In all, about
43 papers were presented, of which 25 were review papers and the remainder reported original work.

In the sessions on organ culture, special mention should be made of the two lectures given by Dame Honor $B$. Fell, one on the technique of organ culture and the other on the application of organ culture to medical and biological research. Other papers on organ culture included: ossification of chick embryo femur growing in liquid media (Prof. H. Endo et al.); incorporation of labelled phosphorus in nucleic acids of human trophoblastic tumours in organ culture (Drs. M. Shee and J. R. Chowdhury); effect of steroid hormones on the chondroitin sulphate metabolism of chick embryo femur growing in vitro (Drs. H. Endo and S. Murota); and biochemical studies on embryonic chick tibia cultivated in vitro (Drs. H. R. Chokshi and C. V. Ramkrishnan).

By far the largest number of papers were read at the animal cell culture sessions, of which the following goneral lectures were of special interest: animal cell culture in cell biology research (Prof. J. Paul); the growth of cells at saline-hydrocarbon interface (Prof. M. D. Rosemberg); carcinogenesis in tissue culture (Prof. H. Katsuta); malignancy of tumour at the cellular level (Prof. H. Katsuta); messenger RNA in animal cells (Prof. J. Paul); culture of differentiating amphibian embryonic cells (Prof. C. H. Waddington); cell contacts and cell movements using tissue culture and biophysical techniques, and the properties of the cell surface (Prof. E. J. Ambrose). Among the original papors presented at the cell culture sessions, mention may be made of the following: effect of steroid hormones on HeLa cells (Prof. H. Endo); studies on normal and cancerous human cervix tissue maintained in vitro in synthetic medium (Prof. C. V. Ramkrishnan et al..); and rat thymus cells in culture (Prof. H. Katsuta). 
In the virology sessions, the following review papers deserve special mention: cell systems for the production of viral vaccines (Dr. M. R. S. Iyengar); application of tissue culture in mammalian tumour virology (Dr. J. R. Chowdhury); and plant viruses in plant and insect tissue cultures (Prof. S. P. Raychowdhury).

The plant tissue culture sessions included several review papers and also a numbor of original papers. Among the review papers may be montionod: fertilization of ovules in vitro (Prof. P. Maheshwari and Dr. K. Kanta); chemical induction of polyembryony (Prof. B. M. Johri); morphogenesis in plant tissue cultures (Dr. H. Y. Mohan Ram); and the role of kinetin in the growth and differentiation of plant tissue and organ cultures (Dr. R. L. N. Sastri). Other papers deseribed the culturing of phylloxera gall and crown gall tissues, loaf and callus tissues. Although Prof. H. E. Street (University of Swansea) could not be present at the seminar as expected, his address, entitled "Plant Tissue Culture in an Interesting Condition", was read. In this, Prof. Street pointed out that plant tissue culture investigations are at present entering a critical phase and made a powerful plea for the maximum exploitation of the potentialities of plant tissue cultures.
Profs. C. H. Waddington and H. Katsuta illustrated their papers by means of ciné films of living cell cultures which were of a high technical excellence and most instructive. Prof. J. Paul gave a course of lectures on the techniques and problems of tissue culture with special reference to animal tissue culture, but those interested in plant tissue culture also found many points of interest in them.

Anyone who sat through all the sessions of the seminar would no doubt have gained the feeling that he had been presented with a broad cross-section of the important advances at present being made in the fields of animal and plant tissue culture.

A somewhat novel feature of the seminar was the ad. vance circulation of mimeographed copies of the complete manuscripts of all papers, which facilitated the discussion following the presentation of each paper. The Proceedings of the seminar will be published shortly by Dr. W. Junk, Publishers, Netherlands.

This report would be incomplete without recording the appreciation of the delegates for the excellent arrangements made by the reception committee, with meticulous attention to detail, and for the hospitality extended to them.

\section{MANAGEMENT STRUCTURE}

U NDER the title Structure in Management, the National Institute of Industrial Psychology has issued a study by Isabel Blain of different forms and their effectiveness *.

Besides a bibliography, the study includes a note on some earlier studies of management in the United Kingdom. The body of the report is based on an enquiry involv. ing interviews with the chief executives of 24 companies engaged in a wide range of activities and detailed questionnaires completed by more than 1,000 managers at other levels. Generally the methods of description used, while tentative, appear to provide a possible basis for devoloping empirical studies in this field, and the provisional analyses of the features which were observed and their relation to effectiveness as reflected in the views of managers have demonstrated several important points for the future development of such studies.

Many factors likely to influence efficiency have been identified, but their individual effects cannot be simple, and vary according to the ways in which they appear in combination. A wide span of control, for example, may be a handicap where there is little delegation, but appropriate in some other circumstances; the importance of organization charts varies with the size and complexity

* National Institute of Industrial Psychology. Report No. 17. Structure in (It) Blain. ${ }_{10}$. of the organization. Methods of classification developed for other purposes can be misleading if used uncritically in studies of particular problems of management organization.

The operational practices within a company may be as important as structures strictly defined, and managerial posts within any company differ in their structural foatures-for example, in level (nearness to the source of authority or decisions), in responsibility to one person or more, in sharing subordinate staff or not, and in the number of others with whom formal operation links must be maintained. Accordingly, Dr. Blain suggests that resoarch could be developed along two lines. First, a study could be made of the extent to which operational features are important, by comparing companies sufficiently similar in size, number of levels, production systems and proportion of specialists, but differing in respect of organization charts, salary administration or procedures for communication. Secondly, comparisons could be made within particular companies having their own operational characteristics, between managerial positions that differ in their structural features, for example, in responsibility to one person or more. In such ways more intensive studies of comparatively small samples are likely to provide evidence bearing directly on these aspects of the organization of management.

\section{ENDEAVOUR}

A CRITICISM often levelled at British industry in tho vital field of overseas exports is that not enough attention is directed to the importanco of making available technical and commercial literature in the language of the country concerned, especially in Europo. In recont years, with increasing representation of British-made goods in overseas markets, especially at international trade fairs and exhibitions, there has been some improvoment in publicity methods in this important matter, chiefly by the larger industrial organizations, but much more could be done to 'put the message over' to a wider audience of potential foreign buyers in their own language.

To a lessor extent this stricture has in the past appliod to scientific literature, but intornationally modern educational standards havo determined at least a working knowledge of three essential languages--English, French and German -and this makes possible intercourse and understanding on an ever-increasing scale in the fields of the arts and sciences as portrayed in many different countries in as many different languages. The growing availability of Russian texts and scientific literature in English and French is a welcome sign of these modern trends.

A particularly impressive example of a multi-lingual scientific publication, one which has been in existence since 1942, is the journal Endeavour, published by Imporial Chemical Industries, London. This is a review of the progress of science, published periodically in five languages-English, French, German, Italian and Spanish. In Endeavour the emphasis is on British science, but 